\title{
Study on relationship between board characteristics and sustainable growth of family listed companies
}

\author{
Xuexin li, Zhenzhen liu, Fengyu Ren \\ Business School of Liaoning University, Research Interest: Business Management, Shenyang, P.R. China
}

Email address:

Lixx_1229@sina.com (Xuexin li), zzliu_90@163.com (Zhenzhen Liu), billren18@hotmail.com (Fengyu Ren)

To cite this article:

Xuexin li, Zhenzhen liu, Fengyu Ren. Study on Relationship between Board Characteristics and Sustainable Growth of Family Listed Companies. Science Journal of Business and Management. Vol. 3, No. 1, 2015, pp. 11-16. doi: 10.11648/j.sjbm.20150301.12

\begin{abstract}
This study explores the relationship between board characteristics and sustainable growth of family listed companies, based on 2009-2012 including 93 family listed companies totally 372 samples. After empirical study, we find that: there is a significant positive correlation between the proportion of independent directors, board meetings, chairman stake and sustainable growth of family listed companies; however, the size of the board directors has a significant negative correlation with sustainable growth of the family listed companies, that is, the more members of the board, the less conducive they are to the sustainable growth of the family business; whether uniting chairman and general manager or not, director's compensation, there is no significant positive correlation with sustainable growth of Family listed companies.
\end{abstract}

Keywords: Family Listed Companies, Board Characteristics, Sustainable Growth

\section{Introduction}

In recent years, the family listed companies have a great impact on China's economic development, so the family of listed companies related research also attracted more and more attention of scholars. Sustainable growth is not only important for the family members within family of listed companies but also significant to the continued stable development of China's national economy.

Sustainable growth of enterprises is expected to overcome an excessive growth or lack of growth in the ideal state. Sustainable growth as Higgins (2001) proposed (Sustainable Growth Rate, referred to as SGR) refers to not exhausting corporate financial resources, the maximum rate of enterprises in terms of sales growth as possible, and affected by business performance and financial policies. For an enterprise, the increase of sales must be maintained by a reasonable increase of assets.SGR can examine whether an enterprise achieves sound development. Wen Yue Chun (2001) held that corporate ownership is highly concentrated in the few people with a certain kinship or relatives of family listed companies, and the "dominance" phenomenon is especially outstanding. In this particular stake in the enterprise, after the family business completing the listing, they will face new opportunities for growth and development environment, the Board of Directors as the main decision-makers whether they will have an impact on sustainable growth of enterprises and how they will affect the sustainable growth?

Most previous studies have focused on how the features of the board of directors influence corporate performance and the value of the family business. There is also some research on the affect of Board of Directors on sustainable growth, but the research on Board Characteristics and family of listed companies is very small. Different from most studies of board characteristics and impact on business performance and corporate value, this paper mainly studies on whether the board characteristics will have an impact on the of sustainable growth in the family of listed companies, as well as how it affects the sustainable growth of enterprises. This paper will be of more practical value than the papers just with simple financial ratio index. The conclusion is more practical significant for a family of listed companies to achieve moderate, sustainable growth.

\section{Literature Review and Hypotheses}

\subsection{CEO Duality and Sustainable Growth}

According to agency theory, whether the information is symmetrical is determined by whether the CEO is duality or not. If the CEO is not duality, there will be agency problems which will increase management costs caused by information asymmetry. Conversely, CEO duality will decrease 
management costs. As chairmen of the family business are mostly headed by the entrepreneur or entrepreneur's relatives, family interests and business interests are closely related. When the chairmen also take as CEO, there will be less information asymmetry and the chairmen will have more information about the development of the company. At the same time, due to their commitment to the maintenance of family interests and their responsibilities, they will make policies to achieve the company's long-term development in line with market demand and corporate development interests. However, CEO duality in family-owned companies may cause corruption and other illnesses of corporate over-power phenomenon, we think that its positive impact is stronger than negative impact. Thus, CEO duality is more conducive to the sustainable growth of the company. Ming An (2012) empirically studied the sustainable growth issues of domestic-foreign trade enterprises and found that CEO duality has a significant positive impact on the sustainable growth of enterprises. Therefore, we hypothesize that:

H1: CEO duality has positive impact on sustainable growth in family listed companies, when the chairman serves as CEO of the family, they are conducive to the sustainable growth of listed companies (see Figure 1).

\subsection{The Size of the Board of Directors and Sustainable Growth}

When the board of directors is mostly constituted by family members with less management knowledge, the greater the size of the board, the greater differences there are in the process of the internal decision-making. The board of directors can hardly seize the development opportunity and easily ignore the risk. Thus it will hinder improving business performance and be more detrimental to the long-term development of family business. Yermack (1996) used the US "Fortune" 500 companies as the study sample and found that business performance was negatively correlated with the size of the board. Yongxiang Sun and Zhang Rong (2000), Jilu Liu and Lingmin Chen (2011) found a negative correlation between the number of directors of listed companies and the company's performance after empirical studies. Poor performance means poor use of financial resources. Therefore, we hypothesize that:

H2: The size of the board of directors in family listed companies has negative impact on sustainable growth, that is, the more the number of directors, the less conducive they are to the sustainable growth of family-owned listed companies (see Figure 1).

\subsection{The Proportion of Independent Directors and Sustainable Growth}

Weisbach and Hermalin (1988) studied the proportion of independent directors and found that increasing the proportion of independent directors, the board can make more effective monitoring of managers and will make decisions that are more conducive to company's development. Xu Erming and Zhang Han (2006) considered that independent directors are introduced from outside the board, not limited by internal staff, so they can provide advice to some extent in impartial and objective manner, and thus make a useful contribution to the realization of the development of enterprises. Thunder (2011) proposed that: the proportion of independent directors of listed companies and the sustainable growth are related, the higher the proportion of independent directors of the company, the more conducive to achieving sustainable growth. Therefore, we hypothesize that:

H3: The proportion of independent directors of listed companies has positive impact on sustainable growth, the existence of the independent directors is in favor of family listed companies to achieve sustainable growth (see Figure 1).

\subsection{The Number of Meetings of the Board and Sustainable Growth}

The Board is mainly through the meetings of the Board to achieve oversight and guidance to managers to make major decisions in favor of the company's development in accordance with the interests of shareholders. Rui Xiang, etc (2010) considered the meetings of the Board as a form of procedure of the Board usually in order to legitimize the decision-making process, and did not discuss substantive issues related business growth, nor the accordingly supervision of decision-making behavior of managers. In China, the board members of listed companies are mostly held by family members and blood closeness will further weaken the role of board meeting in corporate governance. The excessive number of meetings of the Board will propose to increase the company's time and money, wasting internal financial resources worsening the performance, restricting the sustainable growth of enterprises. Vafeas (1999) found that the number of board meetings exists an inverse relationship with company performance, company performance is reactive. Qin Hui, Chen Li (2013) found that the number of board meetings and performance of family listed firm was significantly negatively correlated. Therefore, we hypothesize that:

H4: The number of board meetings has negative impact on sustainable growth, the more the number of meetings of directors is not conducive to achieving sustainable growth in the family of listed companies (see Figure 1).

\subsection{Stake Chairman and Sustainable Growth}

In the study, generally considered that appropriate stake will help improve corporate performance, too low or too high is not good. Guojin Xin, etc (2013) proposed that: Theoretically, if allow a member of the board of directors to hold a certain number of shares, then their economic interests directly linked to business performance, thereby motivating them to monitor operators to increase performance by increasing the company's own interests .In family business, when stake of founder, chairman or family is higher, indicating that their status is higher, the responsibility is greater. The sense of mission and passion for the founder and chairman will consider the benefits and development of the 
entire family to make positive rational decisions which help to reduce financial waste and risks. Therefore, we hypothesize that:

H5: In family listed companies, stake chairman has positive impact on sustainable growth, the higher the stake is, the more conducive the chairman is to achieving sustainable growth (see Figure 1).

\subsection{Directors' Remuneration and Sustainable Growth}

Rui Xiang, Jian Feng's (2008) empirical research on companies said: board members must have sufficient incentives to make their income and services directly linked, otherwise they would not be expected to bear the responsibility of the oversight of the company's major policies After the corresponding material incentives, board members tend to be able to have enough motivation to supervise the management of enterprises, improve the company's operating performance, and they also found that there is a significant positive correlation between the private remuneration of directors of listed companies and operating performance because the family business career and personal development are closely linked. High directors' remuneration will increase its power to promote the development of the company, to enhance the sense of responsibility and have a beneficial impact on the long-term development of the company. Therefore, we hypothesize that:

H6: The remuneration of directors in family listed companies has positive impact on family sustainable growth (Figure 1).

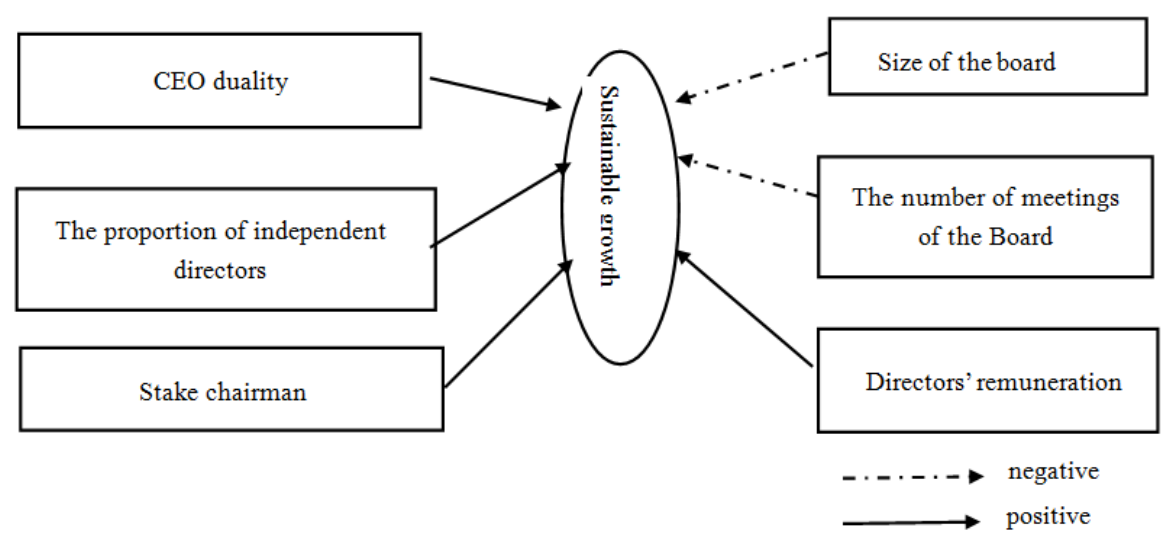

Figure 1. Variable Structure Diagram

\section{Study Design}

\subsection{Study Data Sources and Samples}

This study is the sustainable growth of enterprises and needs the period of continuous analysis, so the sample interval is set to 4 years in this paper. Sustainable growth is a continuous growth, so operations are continuous at least within the sample interval is the duration. Finally intercept all A-share listed companies from 2009 to 2012 between the family listed in Shanghai and Shenzhen stock market trading as a sample. Excluding these enterprises in accordance with the following criteria: (1) excluding the actual control non-business person or family of staff; (2) excluding S, ST, $\mathrm{SST}, \mathrm{S} * \mathrm{ST}$, finance and insurance companies missing data; (3) to ensure the continuity of data, if the sample companies have a year to missing data, other data in this sample companies each year are to be removed; (4) Delete the chairman of the company's data to zero. Finally selected 93 sample companies, a total of 372 four-year data. Financial data for all variables in this article are from the GTA Research Service (CSMAR), using Excel for data collation, SPSS19.0 statistical software for analysis.

\subsection{Definition of Variables}

Explanatory variables (DEVIATION): deviation between sustainable growth rate and the actual growth rate, expressed sustainable growth in assumptions.

$$
\begin{gathered}
\text { DEVIATION }=\frac{|g-s g r|}{|g|+|s g r|} \\
\mathrm{SGR}=\mathrm{P} \times \mathrm{A} \times \mathrm{R} \times \mathrm{T}
\end{gathered}
$$

Which, SGR is the sustainable growth rate; $\mathrm{P}$ is the sales margin; $\mathrm{A}$ is the total asset turnover; $\mathrm{R}$ is the retained earnings ratio; $\mathrm{T}$ is the equity multiplier. $\mathrm{P}$ and $\mathrm{A}$ summarizes the results of the business case, $\mathrm{R}$ and $\mathrm{T}$ reflects the firm's major financial policies.

Actual growth rate $(\mathrm{g})=($ Closing Sales - Beginning sales $/$ beginning of sales)

There may be real growth of abnormal growth or downhill speed, if using the absolute value of the sustainable growth rate with the actual rate of growth, it will make a excessive difference in the data; and DEVIATION is a relative index, taking into account the different enterprises the actual development and can be used to compare different listed companies, to convince strongly. Therefore, this article uses the actual growth rate and sustainable growth rate deviation as dependent variables, the formula of deviation particularly seen in Table 1.

The dependent variable DEVIATION is smaller, indicating the sustainable growth rate is smaller deviating from the actual 
growth rate of the enterprise, meaning the more close to the sustainable growth rate and businesses are more conducive to achieving sustainable growth, and vice versa, the company will not conducive to achieving sustainable growth. In family-owned companies, the board of directors has a great influence on sales, asset turnover, equity multiplier, then greatly affect SGR. So we take the characteristics of board of directors in the corporate governance structure as the main aspects, this paper selects six different angles to reflect the characteristics of the board of directors indicators as independent variables, in order to control impact of other factors on sustainable growth, taking the past related literature findings as reference and selecting a control variable: company size (see Table 1).

Table 1. Variable represents

\begin{tabular}{|c|c|c|}
\hline Classification & Dimensions & Definition \\
\hline $\begin{array}{l}\text { Dependent } \\
\text { variable }\end{array}$ & Deviation & EVIATION $=\frac{|\mathrm{g}-\mathrm{sgr}|}{|\mathrm{g}|+|\operatorname{sgr}|}$ \\
\hline \multirow{2}{*}{$\begin{array}{l}\text { Independent } \\
\text { variable }\end{array}$} & $\begin{array}{l}\text { CEO } \\
\text { Board } \\
\text { INDE }\end{array}$ & $\begin{array}{l}\text { Dummies, if CEO duality, } 1 ; \text { or else, } 0 \\
\text { The number of Board of Directors } \\
\text { Number of independent directors } \\
\text { representing the ratio of the number of } \\
\text { Board of Directors }\end{array}$ \\
\hline & $\begin{array}{l}\text { B_meeting } \\
\text { B_hold } \\
\text { LN_salary }\end{array}$ & $\begin{array}{l}\text { The number of Board of Directors } \\
\text { meetings held during the year } \\
\text { Stake chairman } \\
\text { Logarithm of the total number of } \\
\text { directors on the remuneration of the top } \\
\text { three }\end{array}$ \\
\hline $\begin{array}{l}\text { Control } \\
\text { variables }\end{array}$ & Size & Logarithm of total assets at the end \\
\hline
\end{tabular}

\section{Empirical Analysis}

\subsection{Descriptive Statistics}

Table 2. Descriptive statistics

\begin{tabular}{llllll}
\hline Variables & N & Min & Max & Mean & Std. deviation \\
\hline CEO & 372 & 0 & 1 & 0.330 & 0.470 \\
BOARD & 372 & 5 & 15 & 8.94 & 1.792 \\
INDE & 372 & .300 & 0.571 & 0.369 & 0.047 \\
B_meeting & 372 & 3 & 38 & 8.94 & 3.490 \\
B_hold & 372 & 0.0003 & 69.1074 & 17.971 & 15.6874 \\
LN_salary & 372 & 11.695 & 16.456 & 14.121 & 0.727 \\
Deviation & 372 & 0.00 & 1.00 & 0.6927 & 0.32104 \\
\hline
\end{tabular}

Independent and dependent variables were described statistical analysis, and the results are shown in Table 2. From
Table 2, the mean of the variable CEO is 0.330 , the standard deviation is 0.470 , indicating that about $33 \%$ of family of listed companies is CEO duality, the majority of enterprises are not CEO duality; mean number of board of directors is 8.94 , standard deviation is 1.792 , indicating the size of the board of directors has an average of about nine and there is little difference between companies; the maximum value of the proportion of independent directors is $57.1 \%$, the minimum value $30 \%$, mean 0.369 , standard deviation 0.047 , indicating generally low proportion of independent directors in the family listed companies; the average number of board meetings is 8.94 , the minimum value 3 , maximum value 38 and a standard deviation 3.49 , we can see that there is a big difference in the number of meetings among the companies. Seen from Table 2, the hold of the chairman's stake is in a large gap among different enterprises; mean of DEVIATION is 0.6927, the standard deviation 0.32104, indicating that the majority of family listed companies do not successfully achieve sustainable growth.

\subsection{Correlation Analysis}

Correlation analysis (Table 3) shows that there was a significant negative correlation at the 0.05 level between proportion of independent directors and DEVIATION, indicating that the greater the proportion of independent directors, the smaller the actual growth rate deviates from sustainable growth rate, so for the family of listed companies, the greater proportion of independent Board of directors representing the more favorable; there was a significant negative correlation at the level 0.01 between chairman's stake and DEVIATION, indicating that increased stake is in favor of the chairman to achieve sustainable growth. Number of board meetings and the size of the board have a positive correlation with DEVIATION, indicating increased number of board meetings and expanded size of the board will adversely affected achieving sustainable growth. There was a significant negative correlation between directors' remuneration and DEVIATION, namely to improve the remuneration of board members can promote sustainable growth of enterprises. However, due to the impact of the correlation coefficient analysis did not control other variables, it is only the initial reveal to the relationship between variables (DEVIATION), the specific relationship between the independent and dependent variables needs further empirical testing.

Table 3. Correlation Analysis

\begin{tabular}{|c|c|c|c|c|c|c|c|c|c|}
\hline & & CEO & Board & B_meeting & LN_salary & INDE & B_hold & Size & Deviation \\
\hline \multirow{2}{*}{ CEO } & Pearson & 1 & $-.216^{* *}$ & -.048 & $-.119^{*}$ & $-.152^{* *}$ & $.356^{* *}$ & $-.320^{* *}$ & .029 \\
\hline & Sig.(bilateral) & & .000 & .358 & .022 & .003 & .000 & .000 & .578 \\
\hline \multirow{2}{*}{ Board } & Pearson & $-.216^{* *}$ & 1 & .031 & $.244^{* *}$ & $.831^{* *}$ & $-.354^{* *}$ & $.430^{* *}$ & .081 \\
\hline & Sig.(bilateral) & .000 & & .547 & .000 & .000 & .000 & .000 & .118 \\
\hline \multirow{2}{*}{ B_meeting } & Pearson & -.048 & .031 & 1 & $.123^{*}$ & .054 & -.005 & $.336^{* *}$ & $-.176^{* *}$ \\
\hline & Sig.(bilateral) & .358 & .547 & & .018 & .295 & .917 & .000 & .001 \\
\hline LN_salary & Pearson & $-.119^{*}$ & $.244^{* *}$ & $.123^{*}$ & 1 & $.249^{* *}$ & $-.171^{* *}$ & $.424^{* *}$ & -.071 \\
\hline \multirow{2}{*}{ INDE } & Pearson & $-.152^{* *}$ & $.831^{* *}$ & .054 & $.249^{* *}$ & 1 & $-.291^{* *}$ & $.362^{* *}$ & .008 \\
\hline & Sig.(bilateral) & .003 & .000 & .295 & .000 & & .000 & .000 & .870 \\
\hline
\end{tabular}




\begin{tabular}{|c|c|c|c|c|c|c|c|c|c|}
\hline & & CEO & Board & B_meeting & LN_salary & INDE & B_hold & Size & Deviation \\
\hline \multirow{2}{*}{ B_hold } & Pearson & $.356^{* *}$ & $-.354^{* *}$ & -.005 & $-.171^{* *}$ & $-.291^{* *}$ & 1 & $-.364^{* *}$ & $-.180^{* *}$ \\
\hline & Sig.(bilateral) & .000 & .000 & .917 & .001 & .000 & & .000 & .000 \\
\hline \multirow{2}{*}{ Size } & Pearson & $-.320^{* *}$ & $.430^{* *}$ & $.336^{* *}$ & $.424^{* *}$ & $.362^{* *}$ & $-.364^{* *}$ & 1 & $-.129^{*}$ \\
\hline & Sig.(bilateral) & .000 & .000 & .000 & .000 & .000 & .000 & & .013 \\
\hline \multirow{2}{*}{ Deviation } & Pearson & .029 & .081 & $-.176^{* *}$ & -.071 & .008 & $-.180^{* *}$ & $-.129^{*}$ & 1 \\
\hline & Sig.(bilateral) & .578 & .118 & .001 & .169 & .870 & .000 & .013 & \\
\hline
\end{tabular}

**.at .01 level (bilateral) significance*. at 0.05 level(bilateral) significance.

\subsection{Regression Analysis}

This paper tests the univariate analysis of the model and adds a control variable SIZE to step forward to understand the relationship between the independent variables and the dependent variable. As shown in Table 4, the dependent variable (DEVIATION) has negative correlation with CEO duality, but not statistically significant, indicating the correlation between CEO duality and sustainable growth does not pass the equation test. There was a significant positive correlation with the size of the board and DEVIATION, P $<0.05$, $\mathrm{t}$ value 2.971 , indicating the size of the board has negative impact on achieving sustainable growth and the result is consistent with our hypothesis, expanding the size of the board is not conducive to achieve sustained growth. There is a significant negative correlation between DEVIATION and proportion of independent directors, $\mathrm{P}$ value is 0.002 , $\mathrm{t}$ value of -3.048 , indicating the higher proportion of independent directors is more helpful to achieve sustainable growth and this is also consistent with our hypothesis demonstrating that the establishment of independent directors play a good role in supervision and regulation, which will help the family business to achieve sustainable growth. The correlation between the number of board meetings and DEVIATION was significant negative, increasing the number of board meetings will reduce DEVIATION and will help to achieve sustainable growth of enterprises, which is contrary to our hypothesis 4 . Table 4 shows the existence of stake in the chairman has a significant negative relationship with DEVIATION, indicating a significant positive correlation with sustainable growth, which is consistent with our hypothesis 5 . There is not a significant negative correlation between directors' remuneration and DEVIATION, namely sustainable growth shows no significant positive correlation, hypothesis 6 also does not pass the test equation.

Table 4. Regression results

\begin{tabular}{lllll}
\hline & \multicolumn{2}{l}{ Non-standardized coefficients } & Standard Coefficient & t \\
\cline { 2 - 5 } & B & Standard error & Trial version & -0.255 \\
\hline CEO & -0.009 & 0.037 & -0.014 & 0.799 \\
Board & 0.03 & 0.01 & 0.168 & 0.003 \\
INDE & -1.083 & 0.355 & -0.157 & -971 \\
B_meeting & -0.014 & 0.005 & -0.15 & -3.048 \\
B_hold & -0.005 & 0.001 & -0.261 & -2.765 \\
LN_salary & -0.009 & 0.025 & -0.02 & -4.865 \\
\hline
\end{tabular}

\section{Findings and Conclusion}

The empirical results of this paper show that the characteristics of the board in family listed companies have significant impact on sustainable growth. The main conclusions are:

Conclusion 1: The proportion of independent directors, the stake of chairman and the board meetings are positive to achieve sustainable growth of the family listed companies. After China promulgating the "Regulations on Establishing Independent Director System in Listed Companies guidance", it is modified and perfected in accordance with the effect of the regulations and practiced experiences in listed companies in recent years. The independent directors of listed companies can truly and effectively manage corporate affairs and oversee the company's management to play its intended function. Board meetings in family listed companies better play the role of problem solving and maintenance of sustainable growth. Chairman with a high equity ratio can be responsible for growth and corporate business interests and make decisions conducive to sustainable growth and development of business.
Conclusion 2: The size of board in family listed companies was a significant negative correlation with sustainable growth. Unlike ordinary listed companies, members of the Board of family listed companies are mainly composed of relatives or blood relatives, when the scale is too large can cause more serious internal divisions than ordinary listed companies, and are so seriously influenced by family and personal interests that they are easy to make short-term decision which is not conducive to long-term development of family business, not conducive to achieving sustainable growth of the family business.

Conclusion 3: The impact of CEO duality and the remuneration of the board on sustainable growth is not significant, but still has a positive impact on sustainable growth. Combining the rights of chairman and general manager of the family listed companies, they are powerful to better integrate market information to make decisions in favor of the development of enterprises. Family mission will to some extent curb selfishness of directors, playing a guiding role for the future development of family businesses. Although remuneration and sustainable growth has a positive correlation, you can adjust the remuneration mechanism to 
help achieve sustainable growth of enterprises.

For the current corporate issues including crises of board of directors of listed companies and the problem of sustainable growth, it is important to enhance corporate governance in accordance with the requirements of sustainable and stable growth, to establish and improve the system of the Board of Directors to enhance the power of Board's decision-making, to improve functions of independent directors, to increase the effective number of meetings, to establish a sound incentive and restraint mechanisms, to improve equity ratio of chairman and directors' remuneration, and to enhance the sense of responsibility of decision-making.

\section{Acknowledgments}

The authors thank the support of China Scholarship Council and the fund of National Project Declaration of Liaoning University.

\section{References}

[1] Yuechun Wen, (2001), How to face after the family business listing alternative "dominance"? .Financial Research, 11, pp. $86-91$.

[2] Ming An, (2012), The affect of company's corporate governance structure on sustainable growth, Administered Space, 2, pp. 76-77.

[3] Yermack, D, (1996), Higher Market Valuation for Firms with a Small Board of Directors, Journal of Financial Economics, 40, pp. 185-211.

[4] Yongxiang Sun, Rong Zhang, (2000), Size of the Board of Directors, Corporate Governance and Performance, Business Economy, 10 ,pp. 13-15.

[5] Jilu Liu, Chen Lingmin, (2011), Empirical Study Board Characteristics and Firm Performance [J] Shijiazhuang University of Economics, pp. 554-58.

[6] Hermalin, Weisbach, (1988) The Determinants of Board Composition, Rand Journal of Economics, 18.
[7] Erming Xu, Zhihui Wang, (2000), Correlative Study of Corporate Governance and Strategic Performance Nankai Business Review, 4, pp. 4-14.

[8] Erming $\mathrm{Xu}$, Han Zhang, (2006), Board of Supervision of Listed Companies substitution effect on the performance impact mechanism, Economic Theory and Business Management, 10, pp. 62-67.

[9] Ting Lei, (2011), Sustainable growth of the corporate governance structure and financial, Accounting Communications, 1, pp. 93-95.

[10] Rui xiang, Jian Feng, (2008), Board Characteristics and Operating Performance, Finance and Economics Science, 11, pp. 91-99.

[11] Vafeas, N, (1999), Board Meeting Frequency and Firm Performance, Journal of Financial Economics, p.53.

[12] Hui Qin research, Li Chen, (2013), The board of directors of family listed companies and Enterprise Performance, Modern Property Modern Economy, 10,pp. 51-53.

[13] Jinguo Xin, Linyan Wang, (2013), Impact on the performance of the supervisory board of directors and general manager of the excitation, Technology \& Management Research, 2, pp. 74-79.

[14] Bhagat, S. and Black. B, (1997), Do Independent Directors Matter?. Working paper,

[15] Jensen, M. and Meckling, W, (1976), The Theory the Firm: Managerial Behavior, Agent Costs and Ownership Structure, Journal of Financial Economics, 3, pp.305-360.

[16] Xingjian Fan, Xiaoshu Guo, (2007), Remodeling business model of sustainable growth and enlightenment Accounting Research, 5, pp.39-45.

[17] Shanmin Li, Chenjia Wang, (2004), The concept of family business and morphological classification. Sun Yatsen University, Social Sciences, 3, pp. 66-70.

[18] Robert Higgins $\cdot C \cdot(1998)$, Financial Management Analysis, Beijing: Peking University Press, p.18. 